\title{
Dyskusje o podziale na województwa w Drugiej Rzeczypospolitej
}

\section{Cecylia Leszczyńska}

\section{STRESZCZENIE}

Celem artykułu jest odtworzenie debaty dotyczacej podziału na województwa w Drugiej Rzeczypospolitej, który został wprowadzony w latach 1919-1922. Kształt województw stał się przedmiotem licznych dyskusji, jej uczestnicy zazwyczaj oceniali go krytycznie podkreślając jego nieadekwatność do potrzeb administracji państwowej i wyzwań gospodarczych. Najwięcej projektów przedstawiono w latach 20. XX w. w związku z działalnością trzech komisji rządowo-parlamentarnych pracujących nad koncepcja podziału terytorialnego. Proponowane zmiany miały na celu zatarcie granic byłych zaborów oraz uwzględnienie w nowym podziale na województwa kryteriów demograficznych, ekonomicznych i komunikacyjnych. Projekty te zostały zrealizowane częściowo dopiero w latach 1937-1939, kiedy dokonano przesunięć przede wszystkim granic województw centralnych i zachodnich.

Słowa kluczowe: Druga Rzeczpospolita, podziały terytorialne, polskie województwa

\section{Wstęp}

Wraz z obejmowaniem przez polskie władze administracji nad obszarami nowo budowanego państwa polskiego powstał problem ich podziału na województwa, powiaty i gminy. Najbardziej kontrowersyjnym okazał się podział na województwa, ponieważ w przypadku powiatów i gmin nie zamierzano dokonywać poważniejszych zmian. W grę wchodziły dwa rozwiązania: prostsze - w postaci przemianowania na województwa zaborczych guberni i rejencji, bardziej złożone - w postaci ustanowienia nowych województw. Ostatecznie władze państwa zdecydowały się na to pierwsze rozwiązanie, zastrzegając, że będzie ono miało charakter tymczasowy. Decyzja ta podyktowana była trudną sytuacją wewnętrzna, przemawiała za nią także odmienność porządków prawnych np. w zakresie prawa cywilnego, skarbowego itd. obowiązujących w b. dzielnicach zaborczych, których unifikacja wymagała czasu [Bardach 1985, s. 502-506]. Podział tymczasowy okazał się w praktyce niezwykle trwały, poważniejsze zmiany granic województw przeprowadzono dopiero w końcu lat 30.

Problematyka podziału kraju na województwa stała się przedmiotem licznych debat, w których uczestniczyli politycy, geografowie, ekonomiści i publicyści. Prowadzono je głównie w latach 20. w kontekście prac trzech komisji rządowo-parlamentarnych pracujących nad koncepcja zmian podziału terytorialnego. Zagadnieniom tym poświęcony jest niniejszy artykuł. W pierwszej części przedstawiony został kontekst i przesłanki, jakimi kierowały 
się władze państwowe ustanawiając województwa w latach 1919-1921, w części drugiej pokazano przebieg debaty wokół koncepcji reformy podziału wojewódzkiego. Poważniejsze zmiany granic województw zostały dokonane dopiero w latach 1937-1938.

\section{Województwa w pierwszych latach Drugiej Rzeczypospolitej}

W pierwszych latach Drugiej Rzeczypospolitej podział na województwa wywoływał liczne wattpliwości, jak pisał Wakar część środowisk politycznych była w ogóle przeciwna ich tworzeniu, uznając, że należy poprzestać na bliskich ludności jednostkach powiatowych. Stanowisko to dyktowała niechęć do „znienawidzonych” guberni, na bazie których województwa musiałyby być tworzone [Wakar 1925, s. 12-13]. Województwa jednak utrzymano, zwyciężyły względy pragmatyczne w zakresie zachowania struktur ułatwiających organizację administracji państwowej i samorządowej na poziomie lokalnym.

Ustawy regulujące podział administracyjny ogłaszane były po przejęciu przez Polskę zwierzchnictwa nad kolejnymi dzielnicami. Najwcześniej, bo w dniu 1 sierpnia 1919 r. ogłoszono ustawę o tymczasowej organizacji zarządu b. dzielnicy pruskiej (Dz.Pr.P.P. 1919, nr 64, poz. 385) tworząc Ministerstwo b. dzielnicy pruskiej z siedziba w Warszawie, a minister dzielnicy stał się członkiem Rady Ministrów ${ }^{1}$. Jednocześnie zniesiono stanowisko Naczelnego Prezesa prowincji, w jego miejsce powołano wojewodów stojących na czele dwóch nowo utworzonych województw: poznańskiego i pomorskiego². Jak pisali Wakar i Kumaniecki ustawa de facto przemianowała dawne prowincje pruskie na województwa [Kumaniecki 1921, s. 66; Wakar 1925, s. 13]. Ustawa nie określała siedzib urzędów wojewódzkich, miała je wskazać Rada Ministrów, stosowne rozporządzenie nie zostało ostatecznie wydane. Stolica województwa poznańskiego został Poznań, do stycznia 1920 r. był też stolicą województwa pomorskiego, potem rolę tę pełnił Toruń [Województwo bydgoskie 1967, s. 160].

W tym samym czasie, bo w dniu 2 sierpnia 1919 r. Sejm ogłosił Ustawę tymczasowa o organizacji władz administracyjnych II instancji (Dz.Pr.P.P.1919, nr 65, poz. 395), która poświęcona była ustrojowi władz poziomu wojewódzkiego tzn. urzędowi wojewody i radzie wojewódzkiej. W art. 1 ustawy pojawił się zapis, że do czasu „wejścia w życie ustawy o ustroju administracyjnym Drugiej Rzeczypospolitej” tworzy się województwa warszawskie, łódzkie, kieleckie, lubelskie i białostockie oraz miasto Warszawę jako stolicę państwa. Jak pisał Wakar Sejm Ustawodawczy był zaskoczony nagłym projektem rządu, który złożony został przed wakacjami sejmowymi i wypowiedział się przeciw ustawie. Ostatecznie ją przyją po zapewnieniach ministra spraw wewnętrznych, że jest to rozwiązanie tymczasowe mające ułatwić organizacje administracji [Wakar 1925, s. 12-13]. W załączniku do ustawy

\footnotetext{
${ }^{1}$ Ministerstwo zniesiono w 1922 r. Ustawa z dnia 7 kwietnia 1922 r. w przedmiocie zniesienia Ministerstwa b. Dzielnicy Pruskiej. Dz.U. 1922, nr 30, poz. 247.

${ }^{2}$ Województwo poznańskie składało się z dawnej regencji poznańskiej i części regencji bydgoskiej (objęło ziemie b. Wielkiego Księstwa Poznańskiego oraz przyznane Polsce części powiatów namysłowskiego i sycowskiego, województwo pomorskie objęło pozostałą część regencji bydgoskiej i regencję kwidzyńską).
} 
określono, które powiaty wchodzą do wskazanych pięciu województw, lista ta wskazywała, że województwa utworzono na bazie guberni b. Królestwa Kongresowego ${ }^{3}$. Do ustawy Sejm dołączył rezolucję, w której wezwał rząd do zbadania celowości organizacji władz administracyjnych drugiej instancji oraz rozważenia zmian granic województw.

Organizację województw na terenie b. zaboru austriackiego uregulowano ustawą z 3 grudnia 1920 r. o tymczasowej organizacji władz administracyjnych drugiej instancji (Dz.U. z 1920 r., nr 117, poz. 768)4 . Ponieważ w Galicji nie istniały jednostki poziomu wojewódzkiego, województwa musiano „wykreślić” na nowo. Kwestii ich granic towarzyszyła gorąca dyskusja, padały głosy, że ich granice powinny przecinać linię Curzona, a w danym województwie powinna przeważać ludność polska, zwłaszcza w województwie lwowskim i tarnopolskim [Wakar 1925, s. 13]. Powołano w związku z tym województwo stanisławowskie, które miało oddzielić województwo lwowskie od granicy rosyjskiej i od zwartych skupisk ludności ukraińskiej w województwie wołyńskim [Langrod 1930, s. 97 i 128]. Granice województw miała w przyszłości określić na nowo ustawa o podziale administracyjnym państwa oraz ustawa o samorządzie wojewódzkim. Ustawą grudniową powołano cztery województwa: krakowskie, lwowskie, stanisławowskie i tarnopolskie. Siedzibami urzędów wojewódzkich były odpowiednio Kraków, Lwów, Stanisławów, Tarnopol. Nowy podział zaczął obowiązywać od 1 września 1921 r., kiedy ustały czynności Generalnego Delegata Rządu oraz Namiestnika we Lwowie.

W 1920 r. ustawą z 15 lipca powołano województwo śląskie (Dz.U. z 1920 r., nr 73, poz. 497), obejmowało ono ziemie Śląska Cieszyńskiego i Śląska Górnego ${ }^{5}$. Ustawa zawierała statut organiczny województwa śląskiego, jego wejście w życie nastapiło wraz z pełną przynależnością tych terenów do Polski: w przypadku Śląska Cieszyńskiego od 28 lipca 1920 r., a Górnego Śląska od 15 czerwca 1922 r. [Kokot 1939, s.11]. Województwo to otrzymało znaczną autonomię, a jego stolicą były Katowice.

Najpóźniej powołano województwo na obszarach wschodnich, które objęto polską administracja po zakończeniu wojny z Rosją. Ustawą z 4 lutego 1921 r. (Dz.U. z 1921 r., nr 16, poz. 93 $)^{6}$ rozciagnięto na ten obszar przepisy ustawy z 2 sierpnia 1919 r. o organizacji władz administracyjnych drugiej instancji i utworzono województwa: wołyńskie ze stolicą w Łucku,

\footnotetext{
${ }^{3}$ Województwo lubelskie powstało z b. guberni lubelskiej i siedleckiej, kieleckie - z kieleckiej i radomskiej, łódzkie - z piotrkowskiej i kaliskiej, warszawskie - z warszawskiej i płockiej, białostockie z łomżyńskiej i suwalskiej. Do województwa białostockiego włączono też trzy powiaty guberni grodzieńskiej, a po pokoju ryskim ustawą z dnia 4 lutego $1921 \mathrm{r}$. dołączono jeszcze dwa powiaty tej guberni.

${ }^{4}$ Pełne brzmienie ustawy: Ustawa z dnia 3 grudnia 1920 r. o tymczasowej organizacji władz administracyjnych II instancji (województw) na obszarze b. Królestwa Galicji i Lodomerji z W. Ks. Krakowskiem oraz na wchodzących w skład Rzeczypospolitej Polskiej obszarach Spisza i Orawy. Dodać należy, że Polska otrzymała obszar między Sanem a Zbruczem decyzją Rady Najwyższej Mocarstw z dnia 21 listopada 1919 r. na okres 25 lat z koniecznością nadania mu autonomii. Potem miał zostać przeprowadzony plebiscyt rozstrzygający o jego dalszej przynależności [Kumaniecki 1924, s. 175].

${ }^{5}$ Pełne brzmienie ustawy: Ustawa Konstytucyjna z dnia 15 lipca 1920 r. zawierająca statut organiczny Województwa Śląskiego.

${ }^{6}$ Pełne brzmienie ustawy: Ustawa z dnia 4 lutego 1921 r. o unormowaniu stanu prawno-politycznego na ziemiach przyłączonych do obszaru Rzeczypospolitej na podstawie umowy o preliminaryjnym pokoju i rozejmie podpisanej w Rydze dnia 12 października 1920 r.
} 
poleskie - w Pińsku i nowogródzkie - w Nowogródku7. Powiaty: grodzieński, wołkowyski, białowieski, z wyjątkiem wyznaczonych gmin, przyłączono do województwa białostockiego. Zastrzeżono „rozgraniczenie” województwa nowogródzkiego od mającego powstać w przyszłości województwa wileńskiego. Formalnie utworzono je ustawą z dnia 22 grudnia 1925 r., jego stolicą było Wilno (Dz.U. z 1926 r., nr 6, poz. 29) ${ }^{8}$. Wcześniej jego obszar nazywano Ziemią Wileńską lub Wileńskim Okręgiem Administracyjnym. Spór polsko-litewski o przynależność Wileńszczyzny rozpatrzyć miała Liga Narodów. Nie czekając na jej decyzję Sejm Wileński podjął w dniu 24 marca 1922 r. zatwierdzoną przez polski Sejm Ustawodawczy uchwałę o przyłączeniu tzw. Litwy Środkowej do Polski [Kumaniecki 1924, s. 597-603].

W wyniku opisanych wyżej działań państwo polskie podzielone zostało na 16 województw. W żadnym z nich - z wyjątkiem śląskiego - nie znalazły się obszary należące do dwóch b. państw zaborczych. W nomenklaturze i statystyce międzywojennej przyjęło się grupy województw leżące $\mathrm{w}$ granicach czterech prowincji pozaborczych (Królestwa Polskiego, pruskiej, austriackiej i rosyjskiej) nazywać odpowiednio województwami centralnymi, zachodnimi, południowymi i wschodnimi. Ponieważ ustawodawca zastrzegł, że podział ów miał mieć charakter tymczasowy, w latach 20. spodziewano się jego zmian.

\section{Propozycje reform podziału terytorialnego}

Już 21 lipca 1921 r. do Sejmu wpłynął wniosek grupy posłów z PSL Piast dotyczący podziału wojewódzkiego. Stwierdzono, że potrzebna jest jego gruntowana przebudowa biorąca pod uwagę warunki geograficzne, strukturę gospodarczą oraz aspekty historyczne [Hubert 1922, s. 29-30]. Wniosek zawierał projekt zwiększenia liczby województw do 19 i odtworzenie historycznych województw: kujawsko-chełmińskiego, podolskiego, halickiego i sandomierskiego, ponadto utworzenie województwa kaliskiego, podlaskiego i przemyskiego oraz likwidację tarnopolskiego. Projekt ten nie wszedł pod obrady Sejmu, stał się natomiast przedmiotem wielu dyskusji i krytycznych ocen [Hubert 1922, s. 3-22; Langrod 1931, s. 118; Wakar 1925, s. 14].

W 1923 r. ukonstytuowała się komisja ds. reformy administracji, w której wyodrębniono podkomisję ds. podziału administracyjnego. Podkomisja opowiedziała się przede wszystkim za zmiana granic województw w celu zatarcia linii byłych zaborów. Zaproponowała przesunięcia powiatów z województwa warszawskiego do pomorskiego, z łódzkiego do poznańskiego, z kieleckiego do krakowskiego. Postulowała ponadto likwidację województwa nowogródzkiego (jego powiaty weszłyby do poleskiego i wileńskiego), a także powiększenie pomorskiego kosztem poznańskiego, warszawskiego kosztem białostockiego, wołyńskiego kosztem poleskiego [Podział administracyjny 1929, s. 62-65]. Wskazywała na potrzebe pełnego uzgodnienia

\footnotetext{
${ }^{7}$ Ostatecznie Pińsk nie został stolicą województwa poleskiego z powodu braku pomieszczeń. Rolę tę pełnił Brześć nad Bugiem.

${ }^{8}$ Pełne brzmienie ustawy: Ustawa z dnia 22 grudnia 1925 r. w sprawie utworzenia województwa wileńskiego.
} 
podziału na województwa z podziałem resortowym [Piskozub 1987, s. 174]. Wnioski komisji nie zostały zrealizowane, rewizję istniejącego podziału przesunięto na kolejne lata.

W 1925 r. rząd Aleksandra Skrzyńskiego powołał kolejną komisję (tzw. Komisja trzech) ds. reorganizacji administracji oraz zmiany granic województw [Langrod 1931, s. 119-120]. Na jej ustalenia wpłynęła szeroko dyskutowana kwestia koncepcji województwa jako jednostki samorządowej i jej roli w systemie politycznym kraju. Pojawiły się obawy przed wzmocnieniem samorządów wojewódzkich, uważano, że mogłyby one rywalizować z Sejmem Rzeczypospolitej, a państwo zaczęłoby przypominać federację dużych, samorządnych województw [Wakar 1925, s. 14-15]. Komisja zaproponowała w związku z tym drobne zmiany granic województw w celu zatarcia granic zaborczych z jednej strony, z drugiej powiększenia małych i słabych ekonomicznie województw kosztem województw dużych. Dotyczyć to miało województwa pomorskiego (kosztem poznańskiego), krakowskiego (kosztem kieleckiego), łódzkiego (kosztem kieleckiego). W konsekwencji przesunięcia miały objąć także województwa lubelskie i warszawskie [Langrod 1931, s. 120]. Projekt nie wyszedł poza sferę dyskusji (ryc. 1, 2).

Najszersze prace w zakresie reformy podziału terytorialnego rozwinęła trzecia komisja powołana w 1928 r. przez rząd Kazimierza Bartla, jej oficjalna nazwa to Komisja dla Usprawnienia Administracji Publicznej. W jej skład weszło wielu urzędników najwyższego rzędu, pracowała pod formalnym kierownictwem premiera, faktycznym - ministra spraw wewnętrznych [Łubiarz 2008, s. 216; Przygodzki 2010, s. 317] ${ }^{9}$. Wyniki jej prac zostały opublikowane w jedenastu tomach pod nazwa Materiaty Komisji dla Usprawnienia Administracji Publicznej przy Prezesie Rady Ministrów. Pierwszy tom zawierał referaty opracowane dla sekcji do spraw podziału administracyjnego państwa, tom czwarty materiały ankietowe w sprawie podziału na gminy, powiaty i województwa, tom 5 wnioski w sprawie podziału administracyjnego państwa, tom 8 - ustrój województwa stołecznego i m.st. Warszawy. Prace komisji były szeroko omawiane przez międzywojennych badaczy zajmujących się problematyka podziału terytorialnego, w ostatnich latach opisał je przywołany wyżej Łubiarz [2008] i Przygodzki [2010]. Komisja ogłosiła specjalną ankietę ${ }^{10}$, na którą odpowiedzieli przedstawiciele świata nauki, administracji - bardzo wielu wojewodów i wyższych urzędników administracji publicznej, środowisk gospodarczych oraz osoby prywatne zainteresowane podziałem administracyjnym państwa. Zgłoszone przez nich postulaty przedstawił Łubiarz [Łubiarz 2008, s. 217-243]. Pragnę poniżej zwrócić uwagę na niektóre z projektów, które w swoich dalszych pracach uwzględniła komisja.

\footnotetext{
${ }^{9}$ Przewodniczył jej Maurycy Jaroszyński - były podsekretarz stanu w Ministerstwie Spraw Wewnętrznych, członkami byli: W. Raczkiewicz - wojewoda wileński, W. Roman - były wojewoda poleski, J. Buzek - dyrektor Głównego Urzędu Statystycznego, W. Brzeziński - referent w Ministerstwie Spraw Wewnętrznych. Przy Komisji powołano kilka sekcji, w tym sekcję ds. podziału administracyjnego państwa i organizacji województwa stołecznego [Łubiarz 2008, s. 216].

${ }^{10} \mathrm{~W}$ ankiecie sformułowano pytania dotyczące wielkości województwa i kryteriów je determinujących na okoliczność funkcjonowania województwa jako jednostki administracji ogólnej i województwa jako jednostki samorządu terytorialnego. W odpowiedziach respondenci mieli uwzględnić aspekty regionalne rozumiane jako warunki rozwoju gospodarczego, uwarunkowania geograficzne i komunikacyjne, czynniki rozwoju kulturalnego oraz wymogi administracji zespolonej i niezespolonej (administracja kolejowa, szkolna, skarbowa itd.).
} 


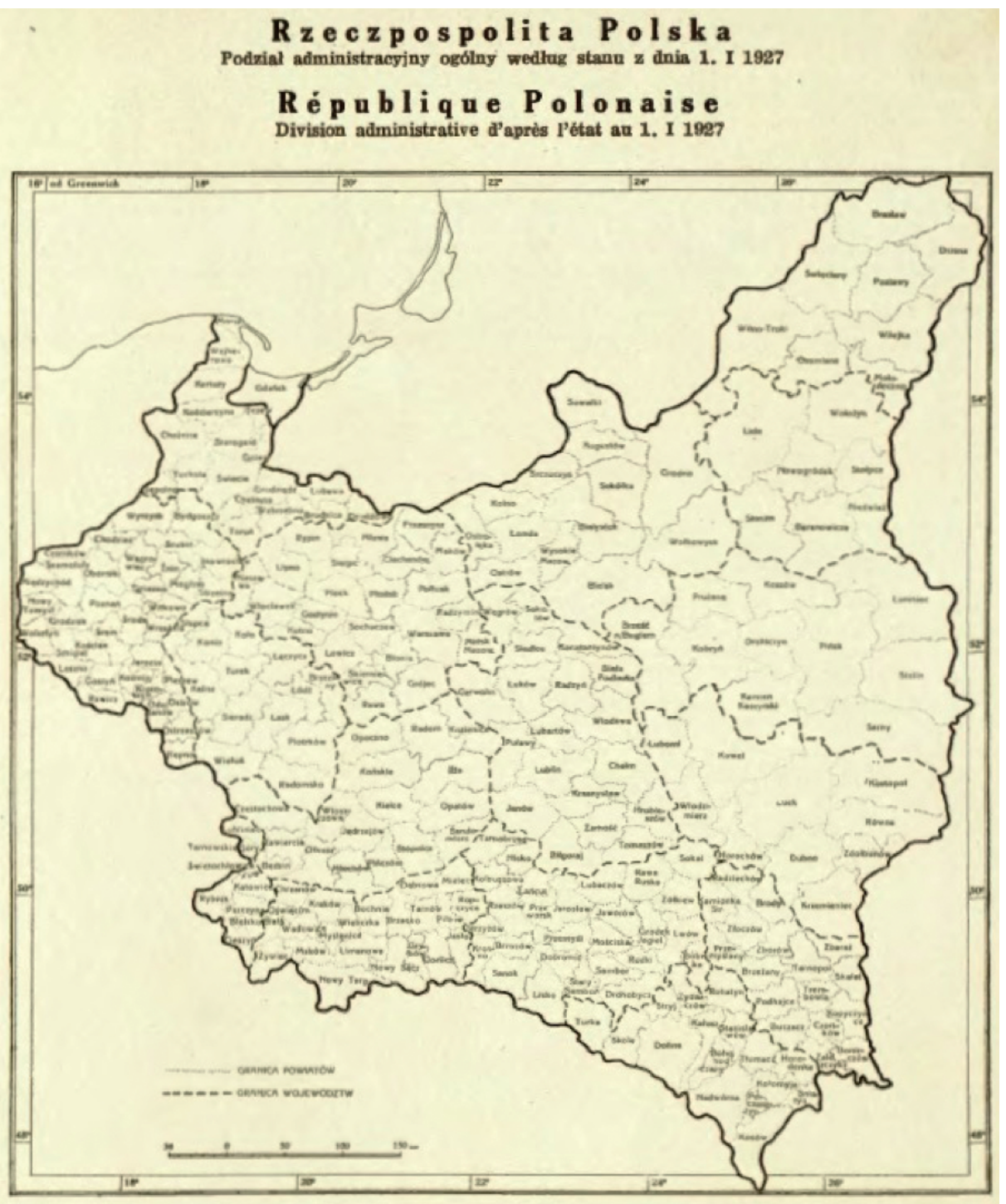

Ryc. 1. Rzeczpospolita Polska. Podział administracyjny ogólny według stanu z dnia 1 stycznia 1927 r. Źródło: Rocznik Statystyki Rzeczypospolitej Polskiej 1927 
I. Analizy i Studia / Analyses and Studies

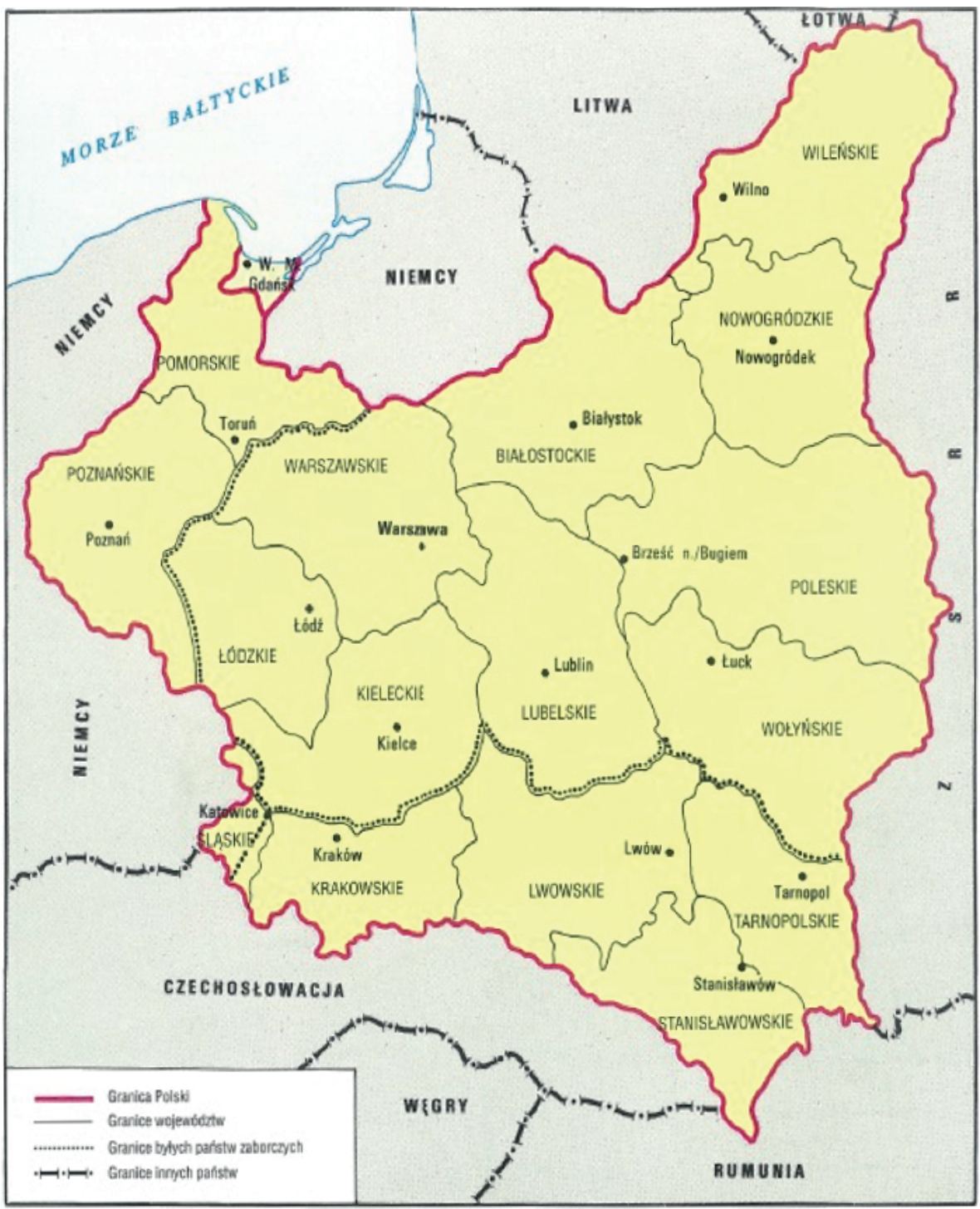

Ryc. 2. Podział administracyjny Polski w 1927 r.

Źródło: A. Jezierski (red.), Historia Polski w liczbach. t.1. Państwo. Społeczeństwo, GUS, Warszawa 2003, s. 256 Wykreślono na postawie mapy zamieszczonej w Roczniku Statystyki Rzeczypospolitej Polskiej 1927, Warszawa 1927 
Ważne postulaty zgłosił Julian Suski, radca ministerialny ministerstwa spraw wewnętrznych. Uważał on, że zasadniczą reformę należy odłożyć na przyszłość, za zasadne uznawał drobne zmiany korygujące błędy podziału z lat 1919-1922. Wymieniał tu utrzymanie granic zaborczych jako granic międzywojewódzkich, brak zgodności podziału wojewódzkiego z terenowymi strukturami administracji niezespolonej oraz pominięcie kryterium komunikacyjnego. Proponował likwidację województwa nowogrodzkiego i tarnopolskiego oraz stworzenie przemyskiego, a w ramach zacierania granic zaborów - przesunięcie granic województw z uwzględnieniem kryterium komunikacyjnego i historycznego [Podziat administracyjny 1929, s. 71-79].

Kolejny projekt przedstawił krakowski statystyk i regionalista Maksymilian Ziomek [Ziomek 1930]. Uważał, że za punkt wyjścia należy wziąć poziom rozwoju gospodarczego województw, by nowe jednostki miały podobny potencjał ekonomiczny, były zbliżone pod względem obszaru i liczby ludności oraz „przełamywały” granice zaborów. Proponował likwidację województwa tarnopolskiego i nowogrodzkiego, utworzenie przemyskiego oraz przesunięcia granic innych województw w wyniku przeniesienia między nimi powiatów. W fazie końcowej widział potrzebę likwidacji województwa śląskiego poprzez włączenie go do krakowskiego.

Niejako równolegle koncepcje podziału wojewódzkiego przedstawili uczeni zajmujący się omawianą tematyką. Jednym z nich był profesor prawa administracyjnego UJ Jerzy Stefan Langrod, który swoje stanowiska wyłożył w pracy Ze studiów nad podziałem administracyjnym państwa i w książce zbiorowej Kraków stolicq kresów południowo-zachodnich - studia nad nowym podziałem administracyjnym państwa [Langrod 1931]. Opowiadał się za zmianami rozłożonymi na trzy etapy z uwagi na zobowiązania międzynarodowe oraz względy samorządowe, gospodarcze, kulturalne, komunikacyjne i różne porządki prawne będące dziedzictwem zaborów. Etap pierwszy mógłby rozpoczać się po ujednoliceniu ustroju samorządów wojewódzkich, tj. pod koniec 1930 r., polegałby na powiększeniu województwa pomorskiego kosztem poznańskiego i warszawskiego, w konsekwencji potrzebne byłyby przesunięcia granic województwa łódzkiego, lubelskiego i białostockiego, a następnie kieleckiego, wileńskiego i poleskiego oraz wołyńskiego. Likwidacji miało ulec województwo nowogródzkie. W drugim etapie - po dokonaniu unifikacji prawnej i reformie samorządów - w latach 1931-1932 proponował likwidacje województwa tarnopolskiego, w celu wzmocnienia wołyńskiego i stanisławowskiego oraz powołanie województwa przemyskiego w wyniku zmian granic województwa krakowskiego, lwowskiego, a w konsekwencji także kieleckiego. Drobne zmiany dotyczyłyby województwa warszawskiego, łódzkiego, poznańskiego, pomorskiego. W efekcie doszłoby do zmniejszenia różnic terytorialnych i ludnościowych, do czterech zmniejszyłaby się liczba województw liczących 2 mln i więcej mieszkańców. Etap trzeci miał nastapić około 1937 r. i dotyczyć likwidacji województwa śląskiego ( $w$ tym roku wygasały zobowiązania określone konwencją genewska z 1922 r.) poprzez połączenie z krakowskim, część powiatów weszłaby dołódzkiego, które autor proponował nazwać łęczycko-sieradzkim. W finale reform proponował zmianę nazw województw na historyczne: białostockiego na podlaskie, kieleckiego na sandomierskie, lubelskiego na lubelsko-bełskie, lwowskiego na podolskie, poznańskiego na poznańsko-kaliskie, stanisławowskiego na halickie (oprócz nich byłoby jeszcze województwo przemyskie 
i warszawsko-grodzkie). Realizacja projektu oznaczałaby stworzenie jednostek spójnych gospodarczo poprzez skupienie w obrębie województwa ośrodków przemysłowych i rolniczych z uwzględnieniem ich wzajemnego ciążenia. Projekt Langroda zawierał również propozycje zmian okręgów tzw. administracji niezespolonej, funkcjonującej obok urzędów wojewódzkich, które powinny pokrywać się z granicami województw bądź ich grup.

Jeszcze inną koncepcję przedstawił statystyk i ekonomista Włodzimierz Wakar, przewidywała ona stworzenie 10 województw (oraz utrzymania jako jednostki wydzielonej m.st. Warszawa) poprzez likwidację 6 województw: białostockiego, kieleckiego, stanisławowskiego, tarnopolskiego, wołyńskiego, nowogrodzkiego i wcielenie ich do pozostałych [Wakar 1928, s. 11-13]. Swoją koncepcję wyłożył także historyk Franciszek Bujak. Uważał, że województwo powinno zajmować obszar od 10 tys. do 25 tys. $\mathrm{km}^{2}$ z $1-2 \mathrm{mln}$ ludności [Bujak 1931]. Wskazywał na błędne wyznaczenia granic województw i ich stolic, krytykował przede wszystkim sztuczne wyodrębnienie województwa stanisławowskiego i tarnopolskiego pisząc: „Lwów był od wieków, jako stolica woj. ruskiego głównym ośrodkiem gospodarczym dla obszaru wschodniej Galicji i pozostał nim mimo podziału tego obszaru na 3 województwa" [Bujak 1931, s. 1].

Propozycje Ziomka, Suskiego i Langroda, jako mające szereg punktów wspólnych, stały się przedmiotem analiz i prac komisji, która opracowała własny projekt. Trafił on do Sejmu jesienią 1931 r. Zawierał propozycję zniesienia 5 województw: białostockiego, kieleckiego, nowogrodzkiego, stanisławowskiego, tarnopolskiego i włączenie ich do województw sąsiednich, ponadto przesunięcie niektórych powiatów między województwami w celu zatarcia granic b. państw zaborczych. Zmiany powyższe uzasadniano koniecznością uwzględnienia stosunków gospodarczych, dążnością do unifikacji administracyjnej państwa, wskazywano na oszczędności finansowe (redukcja administracji) jakie przyniosłoby zmniejszenie liczby województw. Komisja proponowała pozostawienie 12 województw (krakowskie, lubelskie, lwowskie, łódzkie, poleskie, pomorskie, poznańskie, śląskie, warszawskie i stołeczne, wileńskie i wołyńskie) bazujących na następujących regionach administracyjnych: lwowski (łączącym województwa stanisławowskie, tarnopolskie i wschodnią część województwa lwowskiego), wołyński (województwo wołyńskie z pominięciem powiatu sarneńskiego), poleski (Polesie czyli część województwa poleskiego), północno-wschodni, tj. wileński (województwo wileńskie, nowogródzkie oraz wschodnie powiaty białostockiego), lubelski (województwo lubelskie powiatów, które miały wejść do regionu poleskiego i warszawskiego), krakowski (województwo krakowskie i część kieleckiego z Kielcami), śląski (województwo śląskie i krakowskie tworzące wielki okręg przemysłowo-hutniczy), łódzki (województwo łódzkie), poznański (województwo poznańskie i niektóre powiaty z województwa łódzkiego), pomorski (województwo pomorskie plus powiaty województwa warszawskiego i poznańskiego z Bydgoszcza), warszawski (województwo warszawskie i m.st. Warszawa wraz z gminami podmiejskimi) [Przygodzki 2010, s. 323-324].

Projekt Komisji, podobnie jak wcześniejsze, nie został zrealizowany i aż do 1937 r. utrzymał się "tymczasowy" podział z lat 1919-1922. Jego korektę przeprowadzono dopiero w latach 1937-1939, uwzględniała ona przede wszystkim propozycje „zatarcia” granic 
zaborczych. Zmiany przeprowadzono w dwóch etapach. W etapie pierwszym przesunięto granice województw zachodnich i centralnych. Ustawą z 12 czerwca 1937 r., która weszła w życie 1 kwietnia 1938 r., przeniesiono cztery powiaty (lipnowski, nieszawski, rypiński, włocławski) z województwa warszawskiego do pomorskiego, z kolei z pomorskiego do warszawskiego powiat działdowski ${ }^{11}$. Do województwa pomorskiego włączono ponadto powiaty z poznańskiego: bydgoski, inowrocławski, szubiński, wyrzyski i część mogileńskiego (Dz.U. z 1937 r., nr 46, poz. 350). W ten sposób powołano do życia tzw. Wielkie Pomorze, „owoc wieloletnich starań władz lokalnych”, obszar województwa wzrósł o 55\%, a ludność o 73\% [Województwo bydgoskie 1967]. Dokonano ponadto przesunięcia powiatów „łódzkich" do województwa poznańskiego (kaliski, kolski, koniński oraz turecki). W etapie drugim ustawą z 9 kwietnia 1938 r., obowiązującą od 1 kwietnia 1939 r. (Dz.U. z 1938 r., nr 27, poz. 24012), powiększono województwo warszawskie i łódzkie: warszawskie o powiaty "lubelskie” (garwoliński, sokołowski, węgrowski) oraz „,białostockie” (łomżyński, ostrołęcki, ostrowskomazowiecki); łódzkie o powiaty „warszawskie” (kutnowski, łowicki, rawski i skierniewicki) oraz „kieleckie” (koński i opoczyński). W wyniku tych zmian powierzchnia województwa warszawskiego wzrosła z 29,3 do 31,7 tys. km², a łódzkiego z 19,0 do 20,4 tys. km².

Reformy z końca lat 30. XX w. zmieniły - jak z powyższego wynika - powierzchnię i granice województw zachodnich i centralnych, nie ruszono natomiast województw wschodnich i południowych. Pokazuje to poniższa tabela, w której zestawiono powierzchnię województw na początku lat 20. i w końcu 1at 30., ludność województw (wg spisów powszechnych z 1921 i 1931 r.) oraz liczbę powiatów i gmin w 1939 r. (tabela 1, ryc. 3).

Województwa miały bardzo zróżnicowana powierzchnię, niektóre były bliskie makroregionom typu prowincji, inne mikroregionem w postaci dużego powiatu. W odniesieniu do liczby ludności cechowała je duża rozpiętość, widoczna zwłaszcza w przypadku województw wschodnich, które miały bardzo niska gęstość zaludnienia. Widoczne były także duże różnice zagęszczenia sieci miejskiej, jednostek powiatowych i gminnych. Przy tak silnych dysproporcjach demograficznych, ale także gospodarczych, sieci komunikacyjnej itd., trudno było zbudować racjonalny podział terytorialny, zgodny z zasadami gospodarki przestrzennej i właściwą typologią ośrodków regionalnych.

\footnotetext{
${ }^{11}$ Pełny tytuł ustawy: Ustawa z dnia 12 czerwca 1937 r. o zmianie granic województw: poznańskiego, pomorskiego, warszawskiego i łódzkiego.

12 Pełny tytuł ustawy: Ustawa z dnia 9 kwietnia 1938 r. o zmianie granic województw: białostockiego, kieleckiego, lubelskiego, łódzkiego i warszawskiego.
} 
Tabela 1. Województwa Drugiej Rzeczypospolitej

\begin{tabular}{|c|c|c|c|c|c|c|c|c|c|}
\hline \multirow{3}{*}{$\begin{array}{l}\text { Województwa } \\
\text { Polska }\end{array}$} & \multicolumn{2}{|c|}{$\begin{array}{l}\text { Powierzchnia } \\
\text { w tys. } \mathrm{km}^{2}\end{array}$} & \multicolumn{2}{|c|}{$\begin{array}{l}\text { Ludność } \\
\text { w tys. }\end{array}$} & \multicolumn{2}{|c|}{$\begin{array}{c}\text { Ludność } \\
\text { na } 1 \mathrm{~km}^{2} \\
\text { powierzchni }\end{array}$} & $\begin{array}{l}\frac{\lambda}{\pi} \\
\frac{\pi}{3} \\
0 \\
0\end{array}$ & $\stackrel{\mathbb{\pi}}{\stackrel{\mathbb{D}}{\mathbb{I}}}$ & 尝 $\frac{\pi}{\frac{m}{4}}$ \\
\hline & 1922 & $1939^{\mathrm{ab}}$ & 1921 & 1931 & 1921 & 1931 & \multicolumn{3}{|c|}{$1939^{\mathrm{b}}$} \\
\hline & 388,40 & 389,70 & 27177 & 32107 & 70 & 83 & 264 & 611 & 3195 \\
\hline \multicolumn{10}{|c|}{ Województwa centralne } \\
\hline Warszawskie & 29,60 & 31,80 & 3050 & 3701 & 104 & 126 & 26 & 54 & 293 \\
\hline $\begin{array}{l}\text { W tym m.st. } \\
\text { Warszawa }^{c}\end{array}$ & 0,12 & 0,14 & 937 & 1172 & 6645 & 8337 & 4 & 1 & $x$ \\
\hline Łódzkie & 19,00 & 20,40 & 2253 & 2632 & 118 & 138 & 15 & 39 & 237 \\
\hline Kieleckie & 25,60 & 22,20 & 2536 & 2936 & 99 & 115 & 18 & 37 & 275 \\
\hline Lubelskie & 31,20 & 26,60 & 2088 & 2465 & 67 & 79 & 16 & 29 & 228 \\
\hline Białostockie & 32,40 & 26,00 & 1307 & 1644 & 40 & 51 & 10 & 35 & 128 \\
\hline \multicolumn{10}{|c|}{ Województwa wschodnie } \\
\hline Bileńskie & 29,10 & 29,00 & 973 & 1276 & 35 & 44 & 9 & 15 & 96 \\
\hline Nowogródzkie & 22,70 & 23,00 & 824 & 1057 & 35 & 46 & 8 & 10 & 87 \\
\hline Poleskie & 42,30 & 36,70 & 881 & 1132 & 21 & 31 & 9 & 12 & 79 \\
\hline Wołyńskie & 30,30 & 35,70 & 1438 & 2086 & 48 & 58 & 11 & 22 & 103 \\
\hline \multicolumn{10}{|c|}{ Województwa zachodnie } \\
\hline Poznańskie & 26,60 & 28,10 & 1968 & 2107 & 74 & 80 & 29 & 100 & 237 \\
\hline Pomorskie & 16,40 & 25,70 & 936 & 1080 & 57 & 66 & 28 & 64 & 234 \\
\hline Śląskie & 4,20 & 5,10 & 1125 & 1295 & 266 & 308 & 11 & 25 & 463 \\
\hline \multicolumn{10}{|c|}{ Województwa południowe: } \\
\hline Krakowskie & 17,40 & 17,60 & 1993 & 2298 & 114 & 132 & 18 & 47 & 195 \\
\hline Lwowskie & 27,00 & 28,40 & 2718 & 3127 & 101 & 110 & 27 & 58 & 252 \\
\hline Stanisławowskie & 18,40 & 16,90 & 1339 & 1480 & 73 & 87 & 12 & 28 & 119 \\
\hline Tarnopolskie & 16,20 & 16,50 & 1429 & 1600 & 88 & 97 & 17 & 36 & 169 \\
\hline
\end{tabular}

a Łącznie z Zaolziem przyłączonym w $1938 \mathrm{r}$.

b Stan w dniu 1 kwietnia.

c Od 1938 r. województwo grodzkie warszawskie.

Uwaga: ludność na podstawie spisów powszechnych; w podziale według województw nie uwzględniono ludności spisanej przez władze wojskowe: w 1921 r. - 318,5 tys., w 1931 r. - 191,5 tys. W przypadku województw śląskiego i wileńskiego, w których spisu w 1921 r. nie przeprowadzono, liczba ludności na podstawie oszacowań. Źródło: Mały Rocznik Statystyczny 1935, Warszawa 1935, s. 8, 11-14; Rocznik Statystyki Rzeczypospolitej Polskiej 1925/1926, Warszawa 1927, s. 5-10; Mały Rocznik Statystyczny 1939, Warszawa 1939, s. 11 


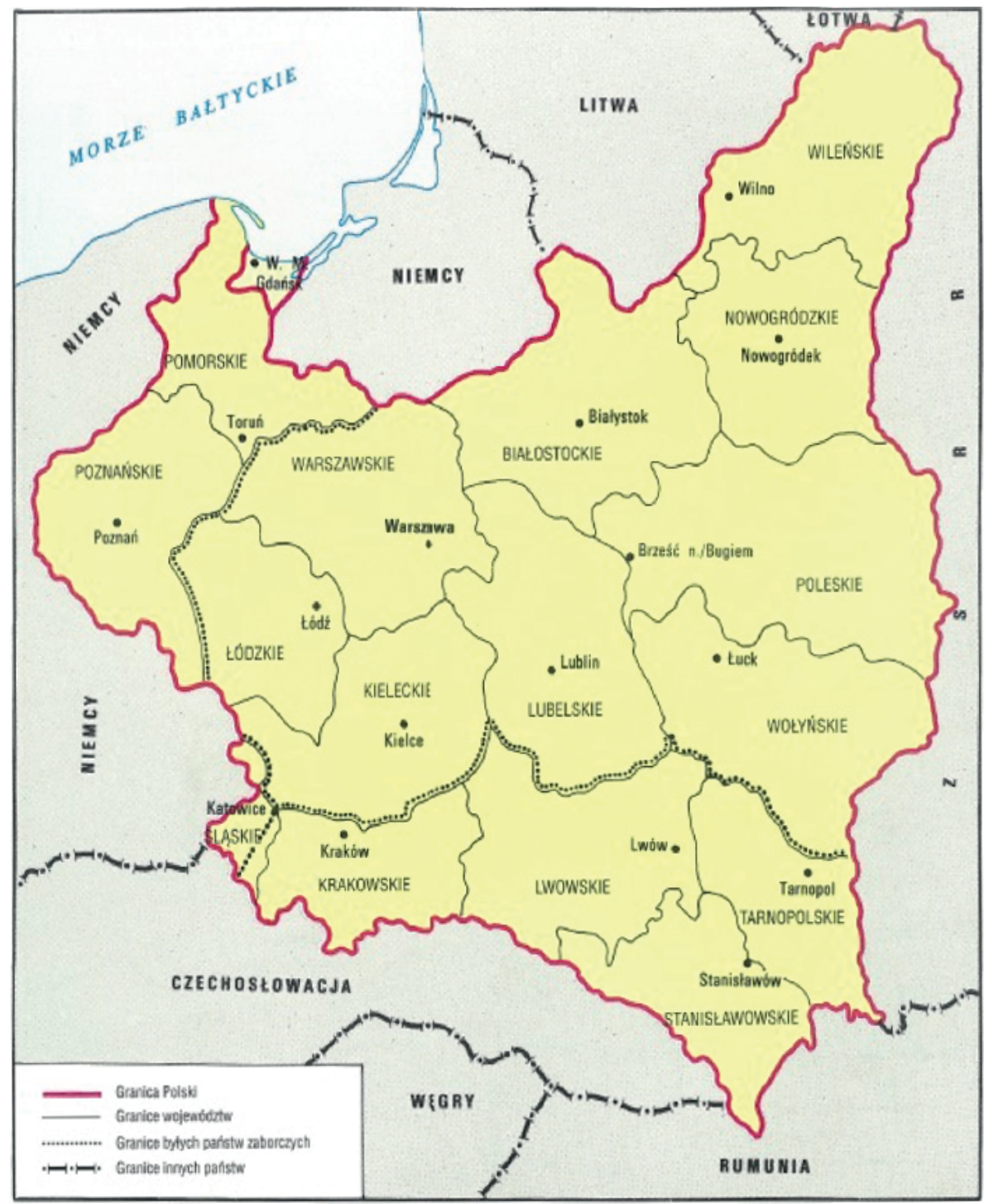

Ryc. 3. Województwa po zmianach administracyjnych lat 1937-1938

Źródło: A. Jezierski (red.), Historia Polski w liczbach. t.1. Państwo. Społeczeństwo, GUS Warszawa 2003, s. 256 Wykreślono na postawie mapy zamieszczonej w Małym Roczniku Statystycznym 1939, Warszawa 1939 
Koncepcje podziału terytorialnego wypływające z koncepcji regionalistycznych, jako istotne kryterium wyodrębniania regionu traktowały gospodarkę. I tak Bujak w pracy Stan gospodarczy Polski [1925] zaproponował podział na 26 dzielnic ekonomicznych Polski opierający się na funkcjach produkcyjnych z uwzględnieniem tradycji historycznej. Wyodrębnił m.in. Wybrzeże Morskie (podstawowym zajęciem ludności było rybactwo i usługi turystyczne), Żuławy Gdańskie (z wysoką kulturą rolniczą oraz stanem przemysłu i handlu), Pojezierze Pomorskie (słabe rolnictwo, niezły przemysł leśny i rybacki), Poznańskie (wysoko rozwinięty handel i przemysł), Śląsk Północny (bogate zasoby naturalne, silnie rozwinięty przemysł i gęsta sieć komunikacyjna), północno-zachodnie Mazowsze (nieźle rozwinięte gospodarczo), Kujawy wschodnie z dorzeczem Bzury (wysoka kultura rolnicza), centrum handlowo-przemysłowe Warszawa-Łódź.

Inną propozycję przedstawił Wakar bazując na obszarach ciążących ku centrom regionalnym. Wymienił 5 prowincji ze stolicami w Warszawie, Krakowie, Poznaniu, Lwowie i Wilnie, uznając je za promieniujące ośrodki gospodarcze. Regionami niższego rzędu były okręgi gospodarcze skupione wokół 28 miast. W ten sposób dzielił kraj na 33 okręgi gospodarcze: w prowincji warszawskiej były to: Warszawa, Płock, Łódź, Piotrków Trybunalski, Radom, Lublin, Siedlce; w krakowskiej - Kraków, Katowice, Bielsko, Częstochowa, Kielce, Tarnów; w poznańskiej - Poznań, Kalisz, Włocławek, Torun, Bydgoszcz, Grudziądz, Gdynia, Gdańsk; we lwowskiej - Lwów, Przemyśl, Stanisławów, Tarnopol, Równe; w wileńskiej - Wilno, Łomża, Białystok, Grodno, Baranowicze, Brześćn. Bugiem, Pińsk. Projekt Wakara spotkał się z krytyką z powodu pominięcia Łodzi, a podniesienia roli Wilna jako ośrodka gospodarczego [Berezowski 1964, s. 83]. Kolejny projekt przedstawił Wakar w pracy Zagadnienia Samorzadu w Rzeczypospolitej Odzyskanej. Analizując sytuację społeczno-polityczną zaproponował stworzenie 12 regionów-województw: Pomorze, Wielkopolska, Mazowsze, Podlasie, Polesie i województwa: łódzkie, częstochowskie, krakowskie, sandomierskie, lubelskie, przemyskie, nowogrodzkie ze stolicami odpowiednio w Toruniu, Poznaniu, Płocku, Białymstoku, Brześciu, Łodzi, Częstochowie, Krakowie, Radomiu, Lublinie, Przemyślu, Słonimiu. Ponadto wyróżnił 7 jednostek rządzących się ustawami specjalnymi: m.st. Warszawa, Śląsk, woj.wileńskie, lwowskie, stanisławowskie, wołyńskie i Wolne Miasto Gdańsk, ze stolicami w Katowicach, Wilnie, Lwowie, Stanisławowie, Tarnopolu i Gdańsku [Wakar 1925, s. 46]. Projekt ten nie był do końca jasny i w zasadzie uwzględniał jedynie aspekt samorządu wojewódzkiego. $Z$ tych zapewne względów nie spotkał się z większym zainteresowaniem.

Zwolennikami oparcia podziału administracyjnego na jednostkach regionalno-prowincjalnych byli m.in. Wakar, Srokowski, Dalbor, Piekałkiewicz czy Rutkowski. Projekty przedstawicieli regionalizmu bazowały na koncepcji regionu, jako obszaru geograficznego odrębnego pod względem cech ekonomicznych społecznych, historycznych i kulturowych, odróżniających od innych obszarów/regionów. Idee te przewijały się także w projektach zgłoszonych do komisji rządowej z 1928 r. Nie zyskały one jednak akceptacji władz rządowych, w ich przeświadczeniu skutkowałyby bowiem decentralizacja państwa. Jak wyjaśniał Langrod: „Nawiązując do tendencji decentralistycznej, regionalizm dąży do pobudzenia 
ośrodków prowincjonalnych w celu samodzielnego i trwałego przejawiania przez nie siły żywotnej bez stałej zależności od centrów państwowych (...). Regionalizm przeciwstawia się nadmiarowi centralizacji, nie neguje jednak centralizacji o tyle, o ile jest ona konieczna. (...) Nie jest koncepcją ustrojowa państwa. Jest bardziej logicznym podziałem władz państwowych" [Langrod 1931, s. 56]. Langrod był przeciwnikiem traktowania regionalizmu jako kryterium podziału administracyjnego: „Reforma administracji w duchu regionalnym byłaby z każdego punktu widzenia szkodliwa dla państwa polskiego, skoro racja stanu w danych warunkach wymaga przeciwstawienia się prądom antyunifikacyjnym" [Langrod 1931, s. 63].

Koncepcje regionalistyczne nie zostały uwzględnione w podziale administracyjnym na województwa. Przyczyną były obawy, iż regionalizm stać się może czynnikiem osłabiającym spójność państwa oraz pozycję instytucji centralnych. Po odzyskaniu niepodległości zasadniczym celem była integracja, towarzyszyły jej tendencje centralistyczne.

\section{Zakończenie}

Problematyka właściwego podziału państwa na jednostki administracyjne była w okresie międzywojennym tematem żywo dyskutowanym. W zasadzie wszyscy uczestnicy debaty, łącznie z czynnikami państwowymi, byli przekonani, że podział na województwa zbudowany w latach 1919-1921 był niewłaściwy i nieadekwatny do potrzeb administracji państwowej i wyzwań gospodarczych. Województwa, terytorialnie bazujące na jednostkach wyższego rzędu z okresu zaborów, nazywano „sztucznymi tworami”, które należało zmienić. Przedstawiane koncepcje zmian można najogólniej podzielić na dwie grupy: 1) zachowanie województw, jako jednostek administracyjnych drugiej instancji, z dokonaniem przesunięć ich granic głównie w celu zatarcia granic zaborczych, 2) likwidację województw bądź ich grupowanie w duże prowincje czy regiony, tworzone na podstawie kryteriów społeczno-gospodarczo-komunikacyjnych. Tego typu jednostki byłyby w stanie prowadzić bardziej samodzielna politykę gospodarczą. Było to istotne w kontekście idei nadania im szerokich uprawnień samorządowych; idea ta nie została jednak ostatecznie zrealizowana. To drugie rozwiązanie prowadziłoby do decentralizacji państwa, temu zaś czynniki polityczne były przeciwne, co było zrozumiałe w sytuacji silnych napięć wewnętrznych i kontekstu międzynarodowego. Z tego też względu zwyciężyła koncepcja pierwsza, ostatecznie zrealizowana w latach 1937-1938.

Województwa Drugiej Rzeczypospolitej były bardzo zróżnicowane pod względem powierzchni, liczby ludności, gęstości zaludnienia oraz poziomu rozwoju gospodarczego. Województwa były w większości słabe ekonomicznie i finansowo, nie były w stanie udźwignąć wyzwań inwestycyjnych, zwłaszcza w zakresie infrastrukturalnym. W systemie administracji państwowej pełniły rolę instancji pośredniczącej między centrum a jednostkami poziomu niższego. Z tym się wiązała rola organów wojewódzkich jako czynnika nadzorującego i kontrolującego instytucje administracyjne i samorządowe poziomu powiatowego i gminnego. Rola organów wojewódzkich, w szczególności urzędu wojewody, była silna, 
a kompetencje szerokie. Rola czynnika obywatelskiego przy wojewodzie, tj. rad i wydziałów wojewódzkich, sprowadzała się najczęściej do opiniowania koncepcji i działań podejmowanych przez wojewodę. Sejmiki wojewódzkie ukonstytuowały się de facto jedynie w Wielkopolsce, odrębna pozycję miał oczywiście Sejm Śląski. Zasadniczo samorząd poziomu wojewódzkiego zajmował w ustroju Drugiej Rzeczypospolitej drugorzędną pozycję.

\section{Literatura}

Bardach J., Leśnodorski B., Pietrzak M., 1985, Historia państwa i prawa polskiego, Wolters Kluwer, Warszawa.

Berezowski S., 1964, Wstęp do regionalizacji gospodarczej, Warszawa.

Bujak F., 1925, Stan gospodarczy Polski, Skł. gł. „Samorząd”, Warszawa.

Bujak F., 1931, Uwagi o projekcie nowego podziału państwa na województwa, Warszawa.

Dziennik Praw Państwa Polskiego z roku 1919.

Dziennik Ustaw Rzeczypospolitej Polskiej z lat 1919-1938.

Hubert J., 1922, Sprawa nowego podziału Rzeczypospolitej Polskiej na województwa, Biblioteka „Przeglądu Administracyjnego", Poznań.

Kokot J., 1939, Zakres działania województwa ślaskiego jako jednostki samorządu terytorialnego, Wydawnictwa Instytutu Śląskiego, Katowice.

Kumaniecki K.W., 1920, Ustrój państwowych władz administracyjnych na ziemiach Polski, Wydawca Leon Frommer, Kraków.

Kumaniecki K.W., 1924, Odbudowa państwowości polskiej. Najważniejsze dokumenty, Nakład Księgarni J. Czarneckiego, Warszawa.

Langrod J.S., 1930, Ze studiów nad podziałem administracyjnym państwa [w:] Kraków stolica kresów południowo-zachodnich. Studia nad nowym podziałem administracyjnym państwa, Izba Przemysłowo-Handlowa, Kraków.

Langrod J.S., 1931, Ze studiów nad podziałem administracyjnym państwa, Gebethner i Wolf, Kraków.

Łubiarz T., 2008, Koncepcje województwa w Materiałach Komisji dla Usprawnienia Administracji Publicznej przy Prezesie Rady Ministrów w II Rzeczypospolitej (1928-1933), „Studia z Dziejów Państwa i Prawa Polskiego", t. XI.

Mały Rocznik Statystyczny, 1935, Główny Urząd Statystyczny Rzeczypospolitej Polskiej, Warszawa.

Mały Rocznik Statystyczny, 1939, Główny Urząd Statystyczny Rzeczypospolitej Polskiej, Warszawa. 
Materiały Komisji dla Usprawnienia Administracji Publicznej przy Prezesie Rady Ministrów: tom I, Podział administracyjny państwa, Warszawa 1929; tom IV: Podział administracyjny państwa, Warszawa 1930; tom V: Podział administracyjny państwa, Warszawa 1931.

Wnioski Komisji, Warszawa 1931.

Piekalkiewicz J., Rutkowski S., 1927, Okręgi gospodarcze Polski, „Kwartalnik Statystyczny”, t. IV, z. 3.

Piskozub A., 1987, Dziedzictwo polskiej przestrzeni, Zakład Narodowy im. Ossolińskich, Warszawa.

Przygodzki J., 2010, Kilka uwag na temat końcowych wniosków Komisji dla Usprawnienia Administracji Publicznej z 1928 roku o podziale administracyjnym państwa na województwa, Acta Universitatis Wratislaviensis, 3270.

Rocznik Statystyki Rzeczypospolitej Polskiej 1925/1926, 1927, Główny Urząd Statystyczny Rzeczypospolitej Polskiej, Warszawa.

Srokowski S., 1930, Podział administracyjny państwa, „Przegląd Geograficzny”, 1-2, (t. 10).

Starzyński R., 1928, Projekt podziału terytorialnego Rzeczypospolitej, Warszawa.

Wakar W., 1925, Zagadnienie samorządu w Rzeczypospolitej Odzyskanej, Warszawa.

Wakar W., 1928, Podział Polski na okregi gospodarcze, „Ekonomista”, R. III.

Województwo bydgoskie, 1967, Krajobraz, dzieje, kultura, gospodarka, Poznań.

Województwo śląskie: 1918-1928: rozwój administracji samorządowej województwa ślaskiego w zarysie, 1929, L. Regorowicz, M. Dworzański, M.W. Tułacz (red.), nakładem Ślasskiej Rady Wojewódzkiej, Katowice.

Województwo tarnopolskie, 1931, nakładem Komitetu Wojewódzkiej Wystawy Rolniczej i Regionalnej, Tarnopol.

Ziomek L., 1930, Podział administracyjny państwa dla celów administracji ogólnej z punktu widzenia potrzeb życia gospodarczego [w:] Kraków stolica kresów południowo-wschodnich, Wydawnictwo Izby Przemysłowo-Handlowej, Kraków. 


\section{Discussion on the division into voivodeships in the Second Polish Republic}

\section{ABSTRACT}

The aim of this article is to reconstruct the debate on the division into voivodeships in the Second Polish Republic, which was implemented in the years 1919-1922. The shape of the voivodeships became the subject of numerous discussions, which participants usually evaluated it critically, stressing its inadequacy to the needs of state administration and economic challenges. The highest number of projects was presented in the 1920s in connection with the activities of three governmental and parliamentary commissions working on the concept of territorial division. The proposed changes were aimed at blurring the borders of the former partitions and taking into account demographic, economic and communication criteria in the new division into voivodeships. These projects were only partially implemented in the years 1937-1939, when mainly the borders of the central and western voivodeships were shifted.

Key words: Second Polish Republic, territorial divisions, polish voivodeships

Cecylia Leszczyńska, dr hab. - jest autorkq̨/współautorkq publikacji z dziedziny historii gospodarczej, statystyki historycznej, historii bankowości i pieniqudza.

Kontakt: Wydział Nauk Ekonomicznych Uniwersytetu Warszawskiego

e-mail: cleszczynska@wne.uw.edu.pl

ORCID: $h$ ttps://orcid.org/0000-0003-4919-7695

Cecylia Leszczyńska, dr hab. (PhD, DSc) - author and co-author of publications in the field of economic history, historical statistics, history of Polish central banking.

Contact: the Faculty of Economic Sciences at the University of Warsaw

e-mail: cleszczynska@wne.uw.edu.pl

ORCID: https://orcid.org/0000-0003-4919-7695 
